\title{
Yaşlı bireylerde sanal ortam yalnızlığı, internet bağımlılığı ve yaşam doyumu ${ }^{1}$
}

\section{Faruk AY 2 \& Gülüşan ÖZGÜN BAŞIBÜYÜK}

Cumhuriyet Üniversitesi, Edebiyat Fakültesi, Antropoloji Bölümü, Sivas / Türkiye Akdeniz Üniversitesi, Sağlık Bilimleri Fakültesi, Gerontoloji Bölümü, Antalya / Türkiye ORCID No: https://orcid.org/0000-0002-6641-4666 ORCID No: https://orcid.org/0000-0002-2801-6157

\begin{abstract}
ÖZET
Bu çalıșmanın amacı 65 yaș üstü bireylere yönelik olarak, sanal ortam yalnızlığı, internet bağımlılığı ve yaşam doyumu arasındaki ilişkilerin belirlenmesidir. Bu amaçla Antalya 60+ Tazelenme Üniversitesinde eğitim gören 65 yaş üstü bireylere anket uygulanmıștır. Araștırmada elde edilen verilerin değerlendirilmesinde SPSS programı kullanılmış ve ortalama, Anova testi, bağımsız örneklem $\mathrm{t}$ testi, korelasyon ve regresyon analizleri yapılmıştır.

Çalıșmada 65 yaș üstü bireylerin yașam doyumu düzeylerinin yüksek olduğu, sanal ortam yalnızlığının orta düzeyde olduğu ve internet bağımlılığı düzeylerinin düşük olduğu saptanmıștır. Kronik hastalığı olmayan bireylerin yaşam doyumlarının daha yüksek olduğu bulunmuştur $(p<0,05)$. Yaşamdan memnuniyet düzeyi "düșük ve orta" olan katılımcılarda internet bağımlılığı daha yüksek bulunmuștur $(p<0,05)$. Yaşamdan memnuniyet düzeyi "iyi ve çok iyi" olanların yaşam doyumları daha yüksek bulunmuştur.

Sonuç olarak sanal ortam yalnızlığı boyutlarından, sanal sosyalleșmenin artması yaşam doyumunu artırmaktadır. İnternet bağımlılığının yaşam doyumuna anlamlı bir etkisi bulunmamıștır $(p>0,05)$. Sanal paylaşım arttıkça internet bağımlılığı artmakta, sanal yalnızlığın artması ise internet bağımlılığını azalmasına neden olmaktadır.
\end{abstract}

\section{MAKALE GEÇMIȘI}

Geliş 02 Mart 2020

Kabul 30 Mayıs 2020

ANAHTAR KELIMELER

Yaşam doyumu, sanal ortam yalnızlığı, internet bağımlılı̆̆ı, yaşlı

\section{Virtual media loneliness, internet addiction and life satisfaction in elderly individuals}

\section{ABSTRACT}

The aim of this study is to determine the relationship between virtual environment loneliness, internet addiction and life satisfaction for individuals over 65 years of age. For this purpose, a questionnaire was applied to individuals over 65 years of age studying at "Antalya $60+$ Tazelenme University". The SPSS program was used to evaluate the data obtained in the study, and the mean, Anova test, independent sample t test, correlation and regression analyses were performed. In this study, it was found that life satisfaction levels of individuals over 65 years of age were high, virtual environment loneliness was moderate and internet addiction levels were low. Individuals over 65 years of age without chronic disease were found to have higher life satisfaction $(p<0,05)$. Internet addiction was found higher in participants whose life satisfaction level was "low and medium" $(p<0,05)$. Life satisfaction levels were found to be higher in those with "good and very good" satisfaction.

As a result, the increase in virtual socialization from the dimensions of virtual media loneliness increases life satisfaction. There was no significant effect of internet addiction on life satisfaction $(p>0,05)$. Internet addiction increased as virtual sharing increased, the increase in virtual loneliness caused a decrease in internet addiction.

\section{ARTICLE HISTORY}

Received 02 March 2020

Accepted 30 May 2020

\section{KEYWORDS}

Life satisfaction, virtual media loneliness, internet addiction, older adult

\section{GİRIS}

Yașam doyumu, kișinin yașamından ne derecede memnun olduğunu belirlemede kendi ölçütlerine göre bilișsel değerlendirmesidir (Kapıkıran, 2016:14). Fiziksel ve zihinsel sağlığın göstergeleri olan yaşam memnuniyeti veya yaşam doyumu görünür yașam kalitesinin önemli bir göstergesidir (Şahin, Özer \& Yanardă̆, 2019:70).

İnsan yașamının farklı dönemlerinde farklı yaşantılar, olumlu veya olumsuz faktörler yaşam

\footnotetext{
${ }^{1}$ Makalenin Kaynak Olarak Gösterimi: Ay, F., \& Özgün Başıüyük, G. (2020). Yaşlı bireylerde sanal ortam yalnızlığı, internet bağımlılı̆̆ ve yaşam doyumu. Yaşlı Sorunları Araştırma Dergisi (YSAD), 13(1), 27-35.

${ }^{2}$ Sorumlu Yazar e-mail: ay.faruk@gmail.com
} 
doyumunu etkileyebilmektedir. Yaşamı olumsuz şekilde etkileyen faktörlerden biri de yalnızlıktır (Kapıkıran, 2016:14).

Yalnızlık, olumsuz bir duygusal duruma yol açan, sosyal desteğin düşük memnuniyeti olarak tanımlanabilir. Yalnızlık aynı zamanda bireyin toplumsal ilişkilerinden öznel memnuniyetsizliğinin bir ölçüsüdür. Yalnızlık, her yaştan insan tarafından yaşanabilecek olumsuz bir duygu halidir (Andrew \& Meeks, 2018:183).

Toplumda yalnızlık sıkıntı verici, problemli olarak görülebilen ve toplumun içinde psikolojik sorunlara yol açabilmekte iken, sanal ortamdaki yalnızlık ise bireyin kendisi tarafından yașanmakta ve birey tarafından fark edilmemektedir. $\mathrm{Bu}$ nedenle sanal yalnızlık problem olarak algılanmadığından sanal ortamlar gerçek hayatın yerine tercih edilebilmektedir (Korkmaz, Usta \& Kurt, 2014:145). Bilgisayar ve internet kullanımı tüm bireylerde olduğu gibi yaşlılarda da artış göstermektedir. Türkiye İstatistik Kurumu'nun (TÜIK) verilerine göre Türkiye'de bireylerin internet kullanım oranı 2019 yılında 16-74 yaş grubundaki bireylerde \%75,3 oldu. Bu oran bir önceki yılda (2018) \%72,9'du. (TÜIKK, 20.05.2020).

Yalnızlık insanların aynı zamanda dijital dünyayla nasıl etkileşime girdiğinin bir belirleyicisi olmaktadır. İnternet kullanımı, mevcut ilişkileri geliştirmek ve yeni sosyal bağlantılar kurmak için yapıldığında yalnızlığı azaltmak için yararlı bir araç olmaktadır. Ancak, sosyal dünyadan kaçmak veya çekilmek için kullanıldığında, yalnızlık duyguları artacaktır. $\mathrm{Bu}$ nedenle yalnız insanlar internet kullanımlarında desteğe ihtiyaç duyacaklardır. Böylece yalnız insanlar bunu yaparken mevcut arkadașlarını ve dostluklarını geliștirecek veya yenilerini taklit edeceklerdir (Nowland, Necka \& Cacioppo, 2018:70).

Yalnızlık; yas, cinsiyet, ırk, sınıf ayrımı olmadan tüm bireylerin yaşamın belli bir döneminde yașayabileceği evrensel bir durumdur. Bununla birlikte en fazla yalnızlık yaşlılık döneminde hissedilmektedir (Şimşek, Küçük Öztürk \& Kaçmaz, 2018). İnternet kullanımının artmasıyla birlikte yalnızlığın yaşandığı ortamlardan biri de sanal ortamlardır. Sanal ortam yalnızlığının belirlenmesi amacıyla üç boyut belirlenmiștir. Birinci boyut olan sanal sosyalleşme, gerçek yaşamda "uygun" sosyallessme durumlarının sanal ortamlardaki iletişim ve etkileşimini ifade etmektedir. İkinci boyut olan Sanal paylașım, sanal ortamda kișilerarası iletișimde her türlü bilgi, resim, müzik, görüș, ideoloji vb. gibi paylaşım faaliyetlerini ifade etmektedir. Üçüncü boyut olan sanal yalnızlık boyutu ise sanal ortamlarda birey olarak var olan ancak başkaları ile etkileșime girmeye ve bir şeyler paylaşmaya pek yanaşmayan, istemese de zaman zaman yanlış anlaşılma yaşayanların durumunu ifade etmektedir (Temel \& Șișman, 2017:173; Korkmaz, Usta \& Kurt, 2014:154).

İnternet bağımlılığının genel olarak nedenleri arasında bireylerin sosyalleșme ihtiyacı, yalnızlıktan kaçınması, gerçek yaşamda kuramadığı bağı internet üzerinden kurabilmesi, düşünce ve duygularını özgürce ifade edebilmesi, diğer insanlarla risk almadan iletișime geçebilmesi ve istediği zaman iletişime girebilmesi gibi nedenler sıralanabilir (Ümmet \& Ekşi, 2016: 34)

İnternetin aşırı ve problemli kullanılmasının sonucunda sosyal anlamda arkadașlık kuramama, aile ile geçirilen vaktin giderek azalması ya da var olan arkadaşlıkların bozulması gibi durumlar görülebilir. Gerçek yaşamda sevgi beslenen kişinin sanal ortamda aranması ve sanal ortamda bu ihtiyacın yeterince doyurulmaması, bireylerin ruh halini olumsuz etkilemektedir (Anl, 2018:393394).

İnternet bağımlılı̆̆ını tedavi etmek için Young tarafından sunulan öneriler ise şu şekildedir: (a) Internet kullaniminda tam tersi bir zamanda yaptırmak, (b) oturumu kapatmasi zamanını hatırlatıcı dis durdurucu kullanmak (zaman alarmı gibi), (c) kısa sürmesi için kullanımda makul hedefler belirlemek (d) bağımlılı̆̆ı artıracak belirli bir uygulamadan kaçınmak, (e) bağımlılı̆̆ın yarattığ sorunları ve vazgeçerse olabilecek faydaları iceren hatırlatma kartlarını kullanmak, (f) kişisel bir envanter geliştirmek, (g) bir destek grubuna girmek ve (h) aile terapisi (Young, 1999:10-14).

Yapılan araștırmalarda așırı internet kullanımının; ev dışındaki sosyal aktivitelere daha az zaman ayrılmasına, eğitsel performansın azalmasına, bireylerin ebeveyn ve arkadaşları ile daha zayıf ilișkiler kurmasına, aile içi iletișimin ve aile içi karșılıklı sosyal desteğin azalmasına neden olduğu belirlenmiş̦tir. Ayrıca aşırı internet kullanımı yalnızlık hissi ve yalnızlıkla ilișkili olduğu belirlenmiștir. (Özen \& Korukçu Sarıcı, 2010:16).

Toplumun artan dijitalleşmesi, yüz yüze görüşmedeki temasın azaltması veya sosyal bağlarının azalması için bir risk faktörü oluşturmasına rağmen, bazı bireyler için yararları da olabilir. Örneğin, sınırlı hareket kabiliyetine sahip yaşlı bireylerin, sosyal ağlarını korumak, sosyal içermeyi artırmak ve refahlarını kolaylaştırmak için dijital teknolojiyi kullanmaları faydalı olabilir. Böylece zaman daha yapıcı olarak geçirilebilmekte ve onların yalnızlık duygularını azaltabilmekte ve bilişsel gerilemeyi önleyebilmektedir (Hill, Betts \& Gardner, 2015:416).

Literatürde yaşlıların sanal ortam yalnızlığı, internet bağımlılığı ve yaşam doyumu ilişkilerini içeren yeterince çalışmaya rastlanılmamıștır. $\mathrm{Bu}$ nedenle gelecek araștırmalar için de bu çalıșma önem taşımaktadır. Yapılan çalıșmalar incelendiğinde Kalınkara ve Sarı (2018:1), Denizli'de $60+$ yaștaki bireyler üzerinde yürüttükleri araştırmalarında, bilgisayar kullanıcısı olan ve olmayan bireylerin teknolojiye karşı tutumlarının farklılık gösterdiğini; bilgisayar kullanıcısı olmayan bireylerin, ergonomik açıdan bilgisayar kullanımıyla ilgili olumsuzluklar belirtikleri ve teknolojiye olumlu bakanların yaşam doyumlarının daha yüksek olduğu belirlemiştir. Sum ark. (2008), araștırmalarında yaşlıların internet kullanımını ve yalnızlıklarını araştırmış ve araștırmasında, interneti bir iletișim aracı olarak daha fazla kullanmanın daha düşük bir sosyal yalnızlık düzeyi ile ilişkili olduğunu, internetin yeni 
insanları bulmak için daha fazla kullanılması ise daha yüksek düzeyde duygusal yalnızlık ile ilişkili olduğunu belirlemiştir. Kapıkıran (2016) 65 yaş üzeri yaşlılara yönelik çalışmasında, sosyal desteğin yalnızlık ile yaşam doyumu arasında kısmi düzeyde aracllığı olduğunu saptamıștır. Şahin ve Yıldırım (2019: 50), yaşlı bireylerde internet kullanımı arttıkça yaşam doyumumun da olumlu etkilendiğini saptamıştır.

Tekedere ve Arpacı (2016), orta yaş ve yaşlılara yönelik çalışmasında, katılımcılardan beğendiği resim, video, yazı gibi şeyleri paylaşmak isteyenler 65 yaş altı bireylerde \%66,7 iken bu oran 65 yaș üstü bireylerde \%41 olarak belirlenmiștir. Görgün Baran ve arkadaşları (2017) çalışmalarında yaşhlların internet teknolojileri ve platformlarına önemli ölçüde hakim olduklarını, bununla birlikte dijital yeterlilik düzeyleri üzerinde demografik unsurların da etkili olduğu belirlenmiştir.

Kalınkara ve Sarı (2019) yaşlıların sosyal ă̆ kullanımları ve yalnızlık arasındaki ilişkilerin incelendiği çalışmalarında, sosyal ağları kullanan yaşlıların daha fazla yalnız yaşayanlar olduğu belirlenmiş ve sosyal ağ boyutlarından iletişim kurma ile sosyal yalnızlık ve sosyal ağ boyutlarından işbirliği sağlama ile duygusal yalnızlık arasında negatif ilişkiler saptanmıştır.

$\mathrm{Bu}$ çalışmanın amacl, yaşlıların sanal ortam yalnızlığı, internet bağımlılığı ve yașam doyumu arasındaki ilişkilerin saptanmasıdır.

\section{YÖNTEM}

Bu çalışmanın temel amacı, 65 yaş üstü bireylere yönelik olarak, sanal ortam yalnızlı̆ı, internet bağımlılığı ve yaşam doyumu arasındaki ilişkilerin belirlenmesidir. Ayrıca yaşlıların sanal ortam yalnızlı̆̆ı, internet bağımlılı̆̆ı ve yașam doyumu düzeylerinin saptanması ve sanal ortam yalnızlığının yaşlıların internet bağlılığına ve yaşam doyumuna etkisinin belirlenmesi de çalışmanın amaçları arasındadır.

Ayrıca araştırmanın diğer alt amaçları şu şekilde sıralanabilir:

- 65 yaş üstü bireylerin sanal ortam yalnızlığı, internet bağımlılı̆̆ı ve yaşam doyumu düzeylerinin belirlenmesi,

- Bazı sosyo-demografik özelliklere göre sanal ortam yalnızlığı, internet bağımlılığı ve yașam doyumu düzeyleri arasındaki farklılıkları belirlemek,

- Sanal ortam yalnızlığının yașam doyumu ve internet bağımlılığı üzerindeki etkisini belirlemek,

- İnternet bağımlılığının yaşam doyumu üzerindeki etkisini belirlemektir.

Çalışmanın hipotezleri ise aşağıdaki gibi belirlenmiştir:

H1: Sanal ortam yalnızlı̆̆ ile sosyo-demografik özellikler arasında (Cinsiyet, medeni durum, eğitim durumu, kronik hastalık ve genel olarak yaşamdan memnuniyet) anlamlı bir fark vardır.

H2: İnternet bağımlılığı ile sosyo-demografik özellikler arasında (Cinsiyet, medeni durum, eğitim durumu, kronik hastalık ve genel olarak yaşamdan memnuniyet) anlamlı bir fark vardır.

H3: Yaşam doyumu ile sosyo-demografik özellikler arasinda (Cinsiyet, medeni durum, eğitim durumu, kronik hastalık ve genel olarak yaşamdan memnuniyet) anlamlı bir fark vardır.

H4: Sanal ortam yalnızlığı boyutlarının yașam doyumu üzerinde anlamlı bir etkisi vardır.

H4a: Sanal Sosyalleşme boyutunun yaşam doyumu üzerinde anlamlı bir etkisi vardır.

H4b: Sanal paylaşım boyutunun yaşam doyumu üzerinde anlamlı bir etkisi vardır.

H4c: Sanal yalnızlığının yaşam doyumu üzerinde anlamlı bir etkisi vardır.

H5: Sanal ortam yalnızlığı boyutlarının internet bağımlılığı üzerinde anlamlı bir etkisi vardır.

H5a: Sanal Sosyalleşme boyutunun internet bağımlılı̆̆ vardır.

H5b: Sanal paylaşım boyutunun internet bağımlılığı üzerinde anlamlı bir etkisi vardır.

H5c: Sanal yalnızlığının internet bağımlılığı üzerinde anlamlı bir etkisi vardır.

H6: İnternet bağımlılığının yaşam doyumu üzerinde anlamlı bir etkisi vardır.

\section{Araştırmanın Evreni ve Örneklemi}

$60+$ Tazelenme Üniversitesi Akdeniz Üniversitesinde yaşları farklı olan (50 ve daha ileri yaşlardaki) bireylerin eğitim aldıkları görülmüştür. Bununla birlikte katılımcllardan sadece 65 yaş ve üzeri olan öğrencilere anket uygulanmıștır. Bu nedenle bu çalışmada $60+$ Tazelenme Üniversitesi Akdeniz Üniversitesinde eğitim gören ve $18-22$ Mart 2019 tarihleri arasında derslere aktif olarak katılan ve yaşları 65 yaş ve üzeri olan 150 kişi araştırmanın evrenini oluşturmuştur. Bu tarihler arasında gönüllü olarak ankete katılan 65 yaş ve üzeri toplam 112 kiși araștırmanın örneklemini oluşturmuștur. Bu sayı \% 5 güven aralığında yeterli görülmektedir samplesize.html)

(http://www.raosoft.com/

\section{Veri Toplamada Kullanılan Anketler}

Araştırmada sosyo demografik özelliklere ilişkin 5 soru sorulmuș ayrıca 8 maddeden olușan İnternet bağımlılığı ölçeği, 5 maddeden oluşan yaşam doyumu ölçeği ve 20 maddeden oluşan sanal ortam yalnızlığı ölçekleri kullanılmıștır. Ölçeklere ilișkin bilgiler şu şekildedir:

1.Internet Bağımlılı̆̆ ÖIçeği (IBÖ): 65 yaş üzeri bireylerin internet bağımlılığını ölçmek amacıyla Young (1998) tarafından geliștirilen 8 maddeden oluşan ölçek kullanılmıştır. Ölçeğin Türkçe uyarlaması Bayraktar (2001) tarafindan gerçekleştirilmiş ve güvenilirlik değeri $=0,910$ olarak belirlenmiștir. Ölçeğe verilen cevaplar 5'li 
likert tipinde "kesinlikle katılmıyorum" ve kesinlikle katılıyorum şeklinde puanlanmıştır.

2.Yaşam Doyumu Ölçeği: 65 yaş üstü bireylerin yaşam doyumunu belirlemek amaciyla Diener, Emmons, Larsen ve Griffin (1985) tarafından geliştirilen beş maddeden oluşan "Yaşam Doyumu Ölçeği (Satisfaction with Life Scale)" kullanılmıştır. Ölçeğin Türkçe geçerlilik ve güvenilirlik çalışması Dağlı ve Baysal (2016) tarafından gerçekleştirilmiş ve Cronbach Alpha iç tutarlık katsayısı $\alpha=0,88$ olarak saptanmıștır. Ölçek 5'li likert türünde "hiç katılmiyorum" ve "tamamen katılıyorum" arasında değișmekte ve puanlanmaktadır (Dağlı \& Baysal, 2016).

3.Sanal Ortam Yalnızlık Ölçeği (SOYÖ): 65 yaşüstü bireylerin sanal ortamlarda yalnızlık düzeylerini belirlemek ve sanal ortamların bireylerin yalnızlaşma durumlarına etkilerini belirlemek amacıyla Korkmaz ve ark. (2014) tarafından geliştirilen ve geçerliliği yapılan "Sanal Ortam Yalnızlığı Ölçeği” kullanılmıştır. Ölçek 5’li Likert tipinde "(1) Hiç yansıtmıyor", "(2) Çok az yansitıyor", "(3) Kismen yansitiyor", "(4) Çok yansitiyor" ve "(5) Tamamen Yansitiyor" șeklinde puanlanmıștır. Ölçek "Sanal Sosyalleșme", "Sanal Paylaşım", "Sanal Yalnızlık" olmak üzere üç boyuttan ve 7 adet olumsuz, 13 adet olumlu ifade olarak toplam 20 maddeden oluşmaktadır. Ölçek boyutlarının güvenilirlik değerleri ise 0,614 ile 0,842 arasından değişmektedir (Korkmaz vd., 2014). Çalıșmamızda "sanal ortamda arkadașım yok" ve "sanal ortamda kimse beni ilgilendirmiyor" maddeleri ölçeğin boyutlarının güvenilirliği düşürdüğünden bu maddeler kapsam dışı bırakılmıș ve toplam 18 maddeden olușan ifadeler kullanılarak analiz edilmiștir.

\section{Verilerin Değerlendirilmesi}

Verilerin değerlendirilmesinde SPSS 22.0 programı aracıllğıyla ortalamalar, ANOVA testi, bağımsız örneklem $t$ testi, korelasyon ve regresyon analizlerinden faydalanılmıştır.

Tablo 1. Ölçeklere ilişkin tanımlayıcı istatistikler

\begin{tabular}{|l|c|c|c|c|c|c|}
\hline & $\begin{array}{c}\text { Cronbach's } \\
\text { Alpha }(\boldsymbol{\alpha})\end{array}$ & $\begin{array}{c}\text { Madde } \\
\text { sayısı }\end{array}$ & Ort. & $\begin{array}{c}\text { Std. } \\
\text { Sapma }\end{array}$ & Min. & Max. \\
\hline Sanal Ortam Yalnızlığı Ölçeği (genel) & 0,824 & 18 & 2,80 & 0,66 & 1,28 & 4,67 \\
\hline Sanal Sosyalleşme & 0,821 & 7 & 3,02 & 0,90 & 1,00 & 5,00 \\
\hline Sanal Paylaşım & 0,918 & 7 & 2,19 & 1,06 & 1,00 & 5,00 \\
\hline Sanal Yalnızlık & 0,803 & 4 & 3,48 & 1,08 & 1,00 & 5,00 \\
\hline İnternet Bağımlılı̆gı & 0,867 & 8 & 1,73 & 0,74 & 1,00 & 5,00 \\
\hline Yaşam Doyumu & 0,881 & 5 & 3,66 & 0,88 & 1,00 & 5,00 \\
\hline
\end{tabular}

Çalışmamızda ölçeklere ilişkin güvenilirlik değerleri yüksek bulunmuştur $(>0,70)$. Katılımcıların ölçeklere verdikleri cevapların ortalamaları incelendiğinde, sırasıyla yaşam doyumu düzeyleri $(3,66)$, sanal yalnızlık $(2,80)$ ve internet bağımlılığı $(1,73)$ olarak belirlenmiştir. Buna göre yaşam doyumu düzeylerinin yüksek olduğu, sanal ortam yalnızlığının orta olduğu ve internet bağımlılığı düzeylerinin düşük olduğu söylenebilir.
Ayrıca sanal ortam yalnızlığı ölçeği boyutlarından sanal yalnızlık boyutunun $(3,48)$ en yüksek ortalamaya sahip olduğu, sanal sosyalleşme $(3,02)$ ve sanal paylaşım $(2,19)$ boyutlarının daha düşük olduğu görülmüştür. Buna göre 65 yaş ve üzeri bireylerin sanal ortamda paylaşımları daha düşüktür. Sanal ortamlardaki sosyalleșme düzeyleri daha yüksekken sanal ortamlardaki yalnızlık düzeylerinin ise en yüksek olduğu söylenebilir.

Tablo 2. Katılımcılara ilișkin tanıtıcı bilgilerin dağılımı

\begin{tabular}{|l|l|c|c|}
\hline \multirow{2}{*}{ Değişkenler } & N & $\%$ \\
\hline \multirow{2}{*}{ Cinsiyet } & Kadın & 75 & 67,0 \\
\cline { 2 - 4 } & Erkek & 37 & 33,0 \\
\hline \multirow{2}{*}{ Medeni durum } & Evli & 59 & 52,7 \\
\cline { 2 - 4 } & Bekar & 53 & 47,3 \\
\hline \multirow{3}{*}{ Eğitim durumu } & Lise ve altı & 52 & 46,4 \\
\cline { 2 - 4 } & Ön lisans & 27 & 24,1 \\
\cline { 2 - 4 } & Lisans ve lisansüstü & 33 & 29,5 \\
\hline \multirow{2}{*}{ Kronik Hastalığınız var mı } & Var & 71 & 63,4 \\
\cline { 2 - 4 } & Yok & 41 & 36,6 \\
\hline \multirow{2}{*}{$\begin{array}{l}\text { Genel olarak Yaşamdan } \\
\text { memnuniyet düzeyi }\end{array}$} & Düșük ve Orta & 16 & 14,3 \\
\cline { 2 - 4 } & İyi & 74 & 66,1 \\
\cline { 2 - 4 } & Cok iyi & $\mathbf{1 1 2}$ & 19,6 \\
\hline Toplam & & & $\mathbf{1 0 0 , 0}$ \\
\hline
\end{tabular}




\section{BULGULAR}

Araştırmaya katılan 65 yaş ve üzeri olan yaşlıların \% 67'sinin kadın, \% 52,7'sinin evli olduğu,\% 46,4'ünün lise ve altı eğitim düzeyine sahip olduğu, $\%$ 63,4'ünün kronik bir hastalığı olduğu belirlenmiştir. Ayrıca katılımcıların \% 66,1'i genel olarak yaşamdan memnuniyet düzeylerini iyi olarak belirtmişlerdir (Tablo 2).

Sosyo-demografik özelliklere göre sanal ortam yalnızlığı, internet bağımlılığı ve yaşam doyumu düzeyleri ANOVA testi ve bağımsız örneklem t testi ile analiz edilmiştir. Bulgulara göre katılımcılar arasında sosyo-demografik özelliklerine göre:

- Cinsiyet, medeni durum ve eğitim açısından sanal ortam yalnızlığı, internet bağımlılığı ve yaşam doyumu düzeylerinde anlamlı bir farklılık saptanmamıștır.

- Kronik hastalığa sahip olma açısından sanal ortam yalnızlığı, internet bağımlılığı düzeylerinde anlamlı bir farklılık saptanmamıştır.

- Kronik hastalığa sahip olma açısından yaşam doyumu düzeylerinde ise farklılık belirlenmiştir. Kronik hastalığa sahip olmayanların yaşam doyumu düzeyleri anlamlı düzeyde yüksek bulunmuştur. Başka bir ifadeyle kronik hastalığı olmayan 65 yaș üzeri bireylerin yaşam doyumu düzeyleri daha yüksektir.

Tablo 3. Sosyo-demografik özelliklere göre sanal ortam yalnızlığı, internet bağımlılı̆̆ı ve yaşam doyumu düzeyleri (Bağımsız örneklem t testi sonuçları)

\begin{tabular}{|c|c|c|c|c|c|c|c|c|c|c|c|c|c|}
\hline \multirow{2}{*}{\multicolumn{2}{|c|}{ Değişkenler }} & \multicolumn{4}{|c|}{ Sanal yalnızlık } & \multicolumn{4}{|c|}{ İnternet bağımlılığı } & \multicolumn{4}{|c|}{ Yaşam doyumu } \\
\hline & & \multirow{2}{*}{$\begin{array}{l}\text { Ort. } \\
2,78\end{array}$} & \multirow{2}{*}{$\begin{array}{c}\begin{array}{c}\text { Std. } \\
\text { Sapma }\end{array} \\
0,66\end{array}$} & \multirow{3}{*}{$\begin{array}{c}\mathrm{t} \\
-0,434\end{array}$} & \multirow{3}{*}{$\begin{array}{c}P \\
0,665\end{array}$} & \multirow{3}{*}{$\begin{array}{l}\text { Ort. } \\
1,75 \\
1,69\end{array}$} & \multirow{3}{*}{$\begin{array}{c}\begin{array}{c}\text { Std. } \\
\text { Sapma }\end{array} \\
0,83 \\
0,52\end{array}$} & \multirow{3}{*}{$\begin{array}{c}\mathrm{T} \\
0,382\end{array}$} & \multirow{3}{*}{$\begin{array}{c}P \\
0,704\end{array}$} & \multirow{3}{*}{$\begin{array}{l}\text { Ort. } \\
3,65 \\
3,67\end{array}$} & \multirow{2}{*}{$\begin{array}{c}\begin{array}{c}\text { Std. } \\
\text { Sapma }\end{array} \\
0,90\end{array}$} & \multirow{3}{*}{$\begin{array}{c}\mathrm{t} \\
-, 095\end{array}$} & \multirow{3}{*}{$\begin{array}{c}P \\
, 924\end{array}$} \\
\hline \multirow{2}{*}{ Cinsiyet } & Kadın & & & & & & & & & & & & \\
\hline & Erkek & 2,84 & 0,66 & & & & & & & & 0,86 & & \\
\hline \multirow{2}{*}{$\begin{array}{l}\text { Medeni } \\
\text { durum }\end{array}$} & Evli & 2,86 & 0,64 & \multirow{2}{*}{0,989} & \multirow{2}{*}{0,325} & 1,72 & 0,69 & \multirow{2}{*}{$-0,196$} & \multirow{2}{*}{0,845} & 3,69 & 0,60 & \multirow{2}{*}{0,342} & \multirow{2}{*}{0,733} \\
\hline & Bekar & 2,73 & 0,67 & & & 1,75 & 0,80 & & & 3,63 & 1,12 & & \\
\hline \multirow{2}{*}{$\begin{array}{l}\text { Kronik } \\
\text { Hastalık }\end{array}$} & Var & 2,83 & 0,66 & \multirow{2}{*}{0,740} & \multirow{2}{*}{0,461} & 1,68 & 0,64 & \multirow{2}{*}{$-0,955$} & \multirow{2}{*}{0,342} & 3,53 & 0,92 & \multirow{2}{*}{$-2,012$} & \multirow{2}{*}{$0,037^{*}$} \\
\hline & Yok & 2,74 & 0,65 & & & 1,82 & 0,88 & & & 3,88 & 0,77 & & \\
\hline
\end{tabular}

${ }^{*} \mathrm{p}<0,05$

“Genel olarak yaşamdan memnuniyet düzeyleri” ile sanal ortam yalnızlığı arasında anlamlı bir farklılık saptanmamıştır. Bununla birlikte katılımcıların genel olarak yaşamdan memnuniyet düzeyleri ile internet bağımlılığı ve yașam doyumları arasında anlamlı bir farklılık saptanmıștır.

İnternet bağımlılığı düzeyi, genel olarak yaşamdan memnuniyet düzeyi "düşük ve orta" olanlarda yașamdan memnuniyet düzeyi "çok iyi" olanlara göre daha yüksek çıkmıştır. Başka bir ifadeyle katılımcıların yaşamdan memnuniyet düzeyi düşük ve orta olanlarda internet bağımlılığı daha yüksektir.

Yaşam doyumu düzeyi, yaşamdan memnuniyet düzeyi "düşük ve orta" olanların, genel olarak yaşamdan memnuniyet düzeyi "iyi ve çok iyi" olanlara göre daha düșük çıkmıștır. Başka bir ifadeyle katılımcıların yaşamdan memnuniyet düzeyi iyi ve çok iyi olanların yaşam doyumları daha yüksektir (Tablo 4). Bu bulgulara göre $\mathrm{H} 1$ hipotezi reddedilmiş, H2 ve H3 hipotezleri kısmen kabul edilmiștir.

Tablo 4. Sosyo-demografik özelliklere göre sanal ortam yalnızlığı, internet bağımlılığı ve yaşam doyumu düzeyleri (ANOVA testi sonuçları)

\begin{tabular}{|c|c|c|c|c|c|c|c|c|c|c|c|c|c|}
\hline \multirow{2}{*}{\multicolumn{2}{|c|}{ Değişkenler }} & \multicolumn{4}{|c|}{ Sanal ortam yalnızlığı } & \multicolumn{4}{|c|}{ İnternet bağımlılığı } & \multicolumn{4}{|c|}{ Yaşam doyumu } \\
\hline & & \multirow{2}{*}{\begin{tabular}{|l|} 
Ort. \\
2,93
\end{tabular}} & \multirow{2}{*}{\begin{tabular}{c|c}
$\begin{array}{c}\text { Std. } \\
\text { Sapma }\end{array}$ \\
0,67 \\
0,60
\end{tabular}} & $\mathrm{~F}$ & $\mathrm{P}$ & Ort. & \begin{tabular}{|c|} 
Std. \\
Sapma
\end{tabular} & $\mathrm{F}$ & $P$ & Ort. & \begin{tabular}{|c|} 
Std. \\
Sapma \\
\end{tabular} & $\mathrm{F}$ & $P$ \\
\hline \multirow{3}{*}{$\begin{array}{l}\text { Eğitim } \\
\text { Durumu }\end{array}$} & $\begin{array}{l}\text { Lise ve } \\
\text { altı }\end{array}$ & & & \multirow{3}{*}{2,251} & \multirow{3}{*}{110} & 1,76 & 0,71 & \multirow{3}{*}{2,331} & \multirow{3}{*}{ 102 } & 3,74 & 0,98 & \multirow[b]{3}{*}{0,470} & \multirow[b]{3}{*}{0,627} \\
\hline & Ön lisans & 2,77 & 0,60 & & & 1,49 & 0,54 & & & 3,54 & 0,76 & & \\
\hline & $\begin{array}{l}\text { Lisans ve } \\
\text { lisansüst } \\
\text { ü }\end{array}$ & 2,62 & 0,64 & & & 1,89 & 0,89 & & & 3,64 & 0,82 & & \\
\hline \multirow{3}{*}{$\begin{array}{l}\text { Genel olarak } \\
\text { Yaşamdan } \\
\text { memnuniyet } \\
\text { düzeyi }\end{array}$} & $\begin{array}{l}\text { Düşük ve } \\
\text { Orta }\end{array}$ & 2,5347 & 0,61359 & \multirow{3}{*}{1,590} & \multirow{3}{*}{0,209} & 2,0313 & 1,07384 & \multirow{3}{*}{3,357} & \multirow{3}{*}{$0,038^{*}$} & 2,9125 & 1,20215 & \multirow[b]{3}{*}{8,548} & \multirow[b]{3}{*}{$0,000^{*}$} \\
\hline & İyi & 2,8356 & 0,61826 & & & 1,7669 & 0,70781 & & & 3,7270 & 0,73023 & & \\
\hline & Çok iyi & 2,8838 & 0,80323 & & & 1,4261 & 0,44764 & & & 4,0000 & 0,83723 & & \\
\hline
\end{tabular}

${ }^{*} \mathrm{p}<0,01$ 
Tablo 5. Sanal ortam yalnızlığı, internet bağımlılığı ve yaşam doyumu değişkenlerine ait korelasyon analizi bulguları

\begin{tabular}{|c|c|c|c|c|c|c|}
\hline & 1 & 2 & 3 & 4 & 5 & 6 \\
\hline 1.Sanal Sosyalleşme & 1 & & & & & \\
\hline 2.Sanal Paylaşım & ,714** & 1 & & & & \\
\hline 3.Sanal Yalnızlık &,$- 221 *$ &,$- 444^{* *}$ & 1 & & & \\
\hline $\begin{array}{l}\text { 4.Sanal Ortam } \quad \text { Yalnızlığ } \\
\text { Ölçeği(genel) }\end{array}$ &, $901^{* *}$ &, $845^{* *}$ &,- 031 & 1 & & \\
\hline 5.İnternet Bağımlılığı & 0,152 & $0,318^{* *}$ &,$- 403^{* *}$ & ,133 & 1 & \\
\hline 6.Yașam Doyumu & $363^{* *}$ & ,383** &,$- 192^{*}$ & ,364** & 041 & 1 \\
\hline
\end{tabular}

** 0.01 düzeyinde anlamlı; * 0.05 düzeyinde anlamlı.

Tablo 5'de sanal ortam yalnızlı̆̆l, internet bağımlılığı ve yaşam doyumuna ilișkin korelasyonlar yer almaktadır. Sanal ortam yalnızlığı ölçeği boyutlarından sanal paylaşım ve sanal yalnızlık boyutu ile internet bağımlılığı arasındaki ilișkiler saptanmıștır. Sanal paylașım boyutu ile internet bağımlılığı $(r=0,318)$ arasında pozitif ve anlamlı bir ilişki saptanmıştır $(\mathrm{p}<0,05)$. Buna göre sanal paylaşım arttıkça internet bağımlılığının arttığı söylenebilir.

Sanal yalnızlık boyutu ile internet bağımlılı̆ğ arasında $(r=-0,403)$ ise negatif ve anlamlı bir ilișki saptanmıștır. Buna göre sanal yalnızlık boyutunda bir artış internet bağımlılığında azalıșa neden olmaktadır. Diğer bir ifadeyle internet bağımlılığında bir artış olması sanal yalnızlık boyutunda bir azalışa neden olmaktadır.

Yaşam doyumu ile sanal ortam yalnızlığı ölçeğinin boyutlarından sanal sosyalleşme $(r=0,363)$, sanal paylaşım $(r=0,383)$ ve sanal yalnızlık (genel) $(\mathrm{r}=0,364)$ arasında pozitif ve anlamlı korelasyon saptanmıştır. Buna göre sanal yalnızlık boyutlarından sanal sosyalleşme ve sanal paylaşımın artması ve sanal ortam yalnızlığının (genel) artması yaşam doyumunda bir artışa neden olmaktadır.

Sanal yalnızlık boyutu ile yaşam doyumu ( $\mathrm{r}=-$ 0,192 ) arasında ise negatif ve anlamlı korelasyon saptanmıştır. Buna göre sanal yalnızlık boyutundaki bir artış yaşam doyumunda azalışa neden olmaktadır.

Tablo 6. Sanal ortam yalnızlığı boyutlarının yaşam doyumuna etkisi

\begin{tabular}{|c|c|c|c|c|c|c|c|c|c|}
\hline \multirow{2}{*}{$\begin{array}{l}\text { Bağımsız } \\
\text { Değişken }\end{array}$} & \multirow{2}{*}{$\begin{array}{l}\text { Bağımlı } \\
\text { Değişken }\end{array}$} & \multicolumn{2}{|c|}{ Modelin özeti } & \multicolumn{2}{|c|}{ ANOVA } & \multicolumn{3}{|c|}{ Regresyon katsayıları } & \multirow[t]{2}{*}{ Sonuç } \\
\hline & & $\mathrm{R}$ & $\mathrm{R}^{2}$ & $\mathrm{~F}$ & $\mathrm{P}$ & Beta & $\mathrm{t}$ & $\mathrm{P}$ & \\
\hline $\begin{array}{l}\text { 1.Sanal } \\
\text { Sosyalleșme }\end{array}$ & \multirow{3}{*}{$\begin{array}{l}\text { Yaşam } \\
\text { doyumu }\end{array}$} & \multirow{3}{*}{0,333} & \multirow{3}{*}{0,111} & \multirow{3}{*}{6,920} & \multirow{3}{*}{0,000} & 0,204 & 2,184 & 0,030 & H4a Kabul \\
\hline 2.Sanal Paylaşım & & & & & & 0,170 & 1,759 & 0,080 & H4b Ret \\
\hline 3.Sanal Yalnızlık & & & & & & 0,018 & 0,231 & 0,818 & H4c Ret \\
\hline
\end{tabular}

Sanal ortam yalnızlığı boyutlarının yașam doyumuna Etkisini belirlemek için çoklu regresyon analizi yapılmıştır. Yaşam doyumunun \% 11'i $\left(\mathrm{R}^{2=}\right.$ 0,11 ) sanal sosyalleșme boyutu tarafından açıklanmaktadır. Sanal sosyalleşmenin yaşam doyumu üzerinde pozitif ve anlamlı bir etkisi vardır $(ß=0,204, t=2,184)$. Sanal ortam yalnızlığı ölçeği boyutlarından sanal paylaşım ve sanal yalnızlığın ise yaşam doyumu üzerinde anlamlı bir etkisi saptanmamıştır (Tablo 6). Buna göre sanal sosyalleşmenin artması yaşam doyumunda da artışa neden olmaktadır.

Sanal ortam yalnızlığı boyutlarının internet bağımlılığına etkisini belirlemek için çoklu regresyon analizi yapılmıștır. İnternet bağımlılığının yaklaşık \%22'si $\left(\mathrm{R}^{2}=0,217\right)$ sanal paylaşım ve sanal yalnızlık boyutları tarafından açıklanmaktadır. Sanal paylaşımın internet bağımlılığı üzerinde ve pozitif ve anlamlı bir etkisi saptanmıştır $(\beta=0,310, t=3,421)$. Sanal yalnızlık boyutunun ise internet bağımlılığı üzerinde negatif ve anlamlı bir etkisi saptanmıștır $(\beta=-0,331, t=-$ 4,590). Buna göre sanal paylaşım boyutu arttıkça internet bağımlılığı artmaktadır. Buna karşın sanal yalnızlık boyutu arttıkça internet bağımlılığı azalmaktadır (Tablo 7).

İnternet bağımlılığının Yaşam doyumuna etkisini belirlemek amaciyla basit regresyon analizi yapılmıştır. İnternet bağımlılığının yaşam doyumuna etkisi anlamlı bulunmamıştır $(\mathrm{P}>0,05)$. (Tablo 8). 
Tablo 7. Sanal ortam yalnızlığı boyutlarının internet bağımlılığına etkisi

\begin{tabular}{|c|c|c|c|c|c|c|c|c|c|}
\hline \multirow{2}{*}{$\begin{array}{l}\text { Bağımsız } \\
\text { Değișken }\end{array}$} & \multirow{2}{*}{$\begin{array}{l}\text { Bağımlı } \\
\text { Değișken }\end{array}$} & \multicolumn{2}{|c|}{ Modelin özeti } & \multicolumn{2}{|c|}{ ANOVA } & \multicolumn{3}{|c|}{ Regresyon katsayıları } & \multirow[t]{2}{*}{ Sonuç } \\
\hline & & $\mathrm{R}$ & $\mathrm{R}^{2}$ & $\mathrm{~F}$ & $\mathrm{P}$ & Beta & $\mathrm{T}$ & $\mathrm{P}$ & \\
\hline $\begin{array}{l}\text { 1.Sanal } \\
\text { Sosyalleşme }\end{array}$ & \multirow{3}{*}{$\begin{array}{l}\text { İnternet } \\
\text { bağımlılığı }\end{array}$} & \multirow{3}{*}{0,466} & \multirow{3}{*}{0,217} & \multirow{3}{*}{15,412} & \multirow{3}{*}{0,000} & $-0,155$ & $-1,772$ & 0,078 & H5a Ret \\
\hline $\begin{array}{l}\text { 2.Sanal } \\
\text { Paylaşım }\end{array}$ & & & & & & 0,310 & 3,421 & 0,001 & H5b Kabul \\
\hline 3.Sanal Yalnızlık & & & & & & $-0,331$ & $-4,590$ & 0,000 & H5c Kabul \\
\hline
\end{tabular}

Tablo 8. İnternet bağımlılığının yașam doyumuna etkisi

\begin{tabular}{|l|l|c|c|c|c|c|c|c|c|}
\hline Bağımsız & Bağımlı & \multicolumn{2}{|c|}{ Modelin özeti } & \multicolumn{2}{|c|}{ ANOVA } & \multicolumn{2}{|c|}{ Regresyon katsayıları } & Sonuç \\
\cline { 5 - 9 } Değişken & Değişken & $\mathrm{R}$ & $\mathrm{R}^{2}$ & $\mathrm{~F}$ & $\mathrm{P}$ & Beta & $\mathrm{t}$ & $\mathrm{P}$ & \\
\hline $\begin{array}{l}\text { İnternet } \\
\text { Bağımlılı̆̆ }\end{array}$ & $\begin{array}{l}\text { Yaşam } \\
\text { Doyumu }\end{array}$ & 0,057 & 0,003 & 0,552 & 0,458 & $-0,057$ & $-0,743$ & 0,458 & H6 Ret \\
\hline
\end{tabular}

\section{TARTIŞMA VE SONUÇ}

$\mathrm{Bu}$ çalışmanın örneklemi, 60+ Tazelenme Üniversitesi Akdeniz Üniversitesinde eğitim gören ve yaşları 65 yaş üstü bireylerdir. Çalışmanın temel amacı 65 yaş üstü bireylere yönelik olarak, sanal ortam yalnızlığı, internet bağımlılı̆̆ı ve yaşam doyumu arasındaki ilişkilerin belirlenmesidir.

Çalışmada katılımcıların sırasıyla yaşam doyumu düzeyleri $(3,66)$, sanal yalnızlık düzeyleri $(2,80)$ ve internet bağımlılığ düzeyleri $(1,73)$ olarak belirlenmiştir. Başka bir ifadeyle katılımcların yaşam doyumu düzeylerinin yüksek olduğu, sanal yalnızlığın orta düzeyde olduğu ve internet bağımlılığı düzeylerinin düşük olduğu söylenebilir.

Çalışmamızda ise 65 yaş üstü bireylerin sanal sosyalleșme düzeyi yüksek, sanal ortam yalnızlık düzeyi ise daha yüksek bulunmuștur. 65 yaș ve üzeri bireylerin sanal ortamda paylaşımları daha düşüktür. Buna göre katılımcıların sanal paylaşımları düșük olsa bile sanal sosyalleșmeyi tercih ettikleri görülmektedir. Bununla birlikte Kalınkara ve Sarı (2019) çalıșmalarında yașlıların sosyal ağ kullanım amaçlarının daha çok sırasıyla içerik paylaşma, iş birliği sağlama ve iletişim kurma olarak saptamışlardır. Ayrıca çalışmalarında yaşlıların sosyal yalnızlık düzeyleri duygusal yalnızlık düzeylerinden daha yüksek olduğu bulunmuştur.

Katılımcıların cinsiyet, medeni durum ve eğitim açısından sanal ortam yalnızlığı, internet bağımlılığı ve yaşam doyumu arasından anlamlı farklar saptanmamıştır.

Katılımcıların kronik hastalığa sahip olma açısından yaşam doyumu düzeylerinde farklılık belirlenmiştir. Kronik hastalığa sahip olmayanların yaşam doyumu düzeylerinin anlamlı düzeyde yüksek bulunmuștur. Bașka bir ifadeyle kronik hastalığı olmayan 65 yaş üzeri bireylerin yaşam doyumu düzeyleri daha yüksek olduğu söylenebilir. Ayrıca buna göre kronik hastalığa sahip olanların ise yaşam doyumu düzeylerinin daha düşük olduğu söylenebilir. Araştırma bulgularımıza benzer olarak Erol ve arkadaşları (2016) yaşlıların kronik hastalığı olmayan yaşlıların yaşam doyumlarını daha yüksek bulmuştur. Bu çalışmada yașlıların cinsiyet, medeni durum ve eğitim açısından yaşam doyumu ve genel yalnızlık düzeyleri arasında anlamlı farklılık olmadığı belirlenmiş ve bu bulgular da çalışmamızı desteklemektedir.

Çalışmamızda genel olarak yaşamdan memnuniyet düzeyleri ile sanal ortam yalnızlığı arasında anlamlı bir farklılık saptanmamıștır. Ancak katılımcıların yaşamdan memnuniyet düzeyi düşük ve orta olanlarda internet bağımlılığı daha yüksek bulunmuştur. Ayrıca katılımcıların yaşamdan memnuniyet düzeyi iyi ve çok iyi olanların yașam doyumları daha yüksek bulunmuştur.

Korelasyon analizi sonucunda, sanal ortam yalnızlığı ölçeği boyutlarından sanal paylaşım boyutu ile internet bağımlılığ $(r=0,318)$ arasında pozitif ve anlamlı bir ilişki saptanmıştır. Buna göre sanal paylaşım arttıkça internet bağımlılığının arttığı söylenebilir. Sanal yalnızlık boyutu ile internet bağımlılığı arasında $(r=-0,403)$ ise negatif ve anlamlı bir ilișki saptanmıștır. Buna göre sanal yalnızlık boyutunda bir artış internet bağımlılığında azalışa neden olmaktadır. Diğer bir ifadeyle internet bağımlılığında bir artıș olması sanal yalnızlık boyutunda bir azalışa neden olmaktadır.

Yașam doyumu ile sanal ortam yalnızlığı ölçeğinin boyutlarından sanal sosyalleşme $(r=0,363)$, sanal paylaşım $(r=0,383)$ ve sanal yalnızlık (genel) $(\mathrm{r}=0,364)$ arasinda pozitif ve anlamlı korelasyon saptanmıştır. Buna göre sanal yalnızlık boyutlarından sanal sosyalleșme ve sanal paylaşımın artması ve sanal ortam yalnızlığının (genel) artması yașam doyumunda bir artışa neden olmaktadır.

Üçüncü boyut olan sanal yalnızlık boyutu ile yașam doyumu $(r=-0,192)$ arasinda ise negatif ve anlamlı korelasyon saptanmıştır. Buna göre sanal yalnızlık 
boyutundaki bir artış yaşam doyumunda azalışa neden olmaktadır. Diğer bir ifadeyle yașam doyumu arttıkça sanal yalnızlık boyutunda yer alan durumlar (sanal ortamda ilișkilerin sahte gelmesi, kendini ifade etmekte zorlanma veya bu ortamda yanlış anlaşılma gibi) azalmaktadır.

Regresyon analizi bulgularına göre, sanal ortam yalnızlı̆̆ı boyutlarından sanal sosyalleșmenin, yaşam doyumu üzerinde pozitif ve anlamlı bir etkisi saptanmıştır. Buna göre sanal sosyalleşmenin artması, yaşam doyumunda da artışa neden olmaktadır.

İnternet kullanımı, mevcut iliş̧ileri geliştirmek ve yeni sosyal bağlantılar kurmak için yapıldığında yalnızlığı azalttığını belirlemiștir (Nowland, 2018:70; Moody, 2001; Sum, Mathews, Hughes, \& Campbell, 2008). Yukarıda ifade edildiği gibi, yaşam doyumunu olumsuz etkileyen faktörlerden en önemlilerinden biri de yalnızlıktır. Buna göre araştırma bulgularımızda sanal sosyalleşmenin artmasının yaşam doyumunu artırması, yaşlıların yalnızlığının azalmasında da katkı sağladığını söyleyebiliriz.

Araştırmamızda sanal ortam yalnızlığı boyutlarından sanal paylaşım ve sanal yalnızlığın internet bağımlılığı üzerinde anlamlı bir etkisi saptanmıştır. Bununla birlikte Sanal paylaşımın internet bağımlılığı üzerinde ve pozitif ve anlamlı bir etkisi belirlenmişken, sanal yalnızlık boyutunun ise internet bağımlılığı üzerinde negatif ve anlamlı bir etkisi saptanmıștır. Buna göre sanal paylașım boyutu arttıkça internet bağımlılığı artmaktadır. Buna karşın sanal yalnızlık boyutu arttıkça internet bağımlılı̆̆ azalmaktadır.

Ayrıca çalışmamızda internet bağımlılığının yaşam doyumu üzerinde anlamlı bir etkisi saptanmamıştır. Literatürde yaşlılara yönelik internet bağımlılığı ile değil de daha çok internet kullanımlarına yönelik çalıșmalara rastlanılmıștır. $\mathrm{Bu}$ çalışmalarda araştırma bulgularımızdan farklı olarak Şahin ve Yıldırım'ın (2019) araştırmasında yaşlı bireylerde internet kullanımı arttıkça yaşam doyumumun da olumlu etkilendiği saptanmıștır. Karavidas, Lim ve Katsikas (2005) yaşlıların bilgisayar kullanımının öz-yeterliği artırmaya ve bilgisayar kaygısını azaltmaya yardımcı olarak genel yaşam doyumu düzeyini artırdığını ortaya koymuştur. Lissitsa ve Chachashvili-Bolotin, (2016) son 10 yıl içinde değişimleri incelemek için tekrarlanan kesitsel çalışmalarında, internet kullanan bireylerde yaşam doyumunun 18-64 yașları arasında arttığını ve yașlılar arasında ise sabit kaldığını belirlemişlerdir. İnternetin benimsenmesinin yașam doyumunu arttırdı ğ belirlenmiştir. Buna karşın, Stepanikova, Nie ve He'nin (2010) çalışmalarında yaşlılarda internette harcanan zamanın yașam doyumunu negatif yönde etkilediği belirlenmiștir.

Sonuç olarak 65 yaş üstü bireylerin yaşam doyumlarının artmasında internet bağımlılığının katkısı olmadı̆̆ı söylenebilir. Bununla birlikte yaşlıların bağımlılık olmadan, sanal sosyalleşme amacıyla internet kullanımları onların yaşam doyumlarının artmasında ve yalnızlığın azalmasına olumlu katkılar sağlayacağı söylenebilir. Sanal sosyalleşme sayesinde yaşlıların gerçek yaşamlarında da ilişkilerin ve etkileşimin artmasının sağlanmasında katkı sağlayabilir.

Yaşlıların sanal paylaşımlarının (resim, bilgi, görüş gibi paylaşımlarının artması) çok sık olması onları internet bağımlılı̆̆ına götürebilmektedir. Ayrıca sanal ortamlarda yalnızlık arttıkça, başkalarıyla bir şeyler paylaşmayı tercih etmediklerinden yaşlıların internet bağımılılığının azalmasına katkı sağlamaktadır.

Bu çalışma 60+ Tazelenme Üniversitesi Akdeniz Üniversitesinde eğitim gören yaşlılarla sınırlıdır. Yaşlılara yönelik farklı daha geniş gruplara ulașılarak yeni çalıșmaların yapılması araștırma bulgularının geçerliliğine katkı sağlayacaktır. Ayrıca literatürde yaşlılara yönelik internet kullanımı ile ilgili çalışmaların olmasına karşın; bundan sonra yapılacak çalışmalar için yaşlılara yönelik internet bağımlılığı ile ilgili yeni çalışmalara ihtiyaç vardır. Yaşlıların internet bağımlılığı, yaşam doyumu ve sanal ortam yalnızlığının birlikte çalışıldığı araştırmaların sınırlı olması, benzer çalışmaların yapılmasına ihtiyaç olduğunun önemini göstermektedir.

\section{Teşekkür}

$\mathrm{Bu}$ araştırmanın yapılmasına olanak sağlayan $60+$ Tazelenme Üniversitesi kurucusu Prof. Dr. İsmail Tufan'a ve araștırmaya gönüllü katılım gösteren $60+$ Antalya Tazelenme Üniversitesi öğrencilerine teșekkür ederiz.

\section{Çıkar Çatışması}

Yazarlar tarafından herhangi bir çıkar çatışması beyan edilmemiștir.

\section{KAYNAKÇA}

Andrew, N., \& Meeks, S. (2018). Fulfilled preferences, perceived control, life satisfaction, and loneliness in elderly longterm care residents, Aging \& Mental Health, 22,2, 183-189, DOI:10.1080/13607863. 2016.1244804

Anlı, G. (2018). İnternet bağımlılığı: Sosyal ve duygusal yalnızlık. Uluslararası Bilimsel Araștırmalar Dergisi (IBAD), 3(2), 389-397.

Bayraktar, F. (2001). Ergenlik Döneminde Internet Kullanımının Rolü. Yayınlanmamış Yüksek Lisans Tezi, İzmir, Ege Üniversitesi, Sosyal Bilimler Enstitüsü.

Dağlı, A., \& Baysal, N. (2016). Yaşam doyumu ölçeğinin Türkçe 'ye uyarlanması: Geçerlik ve güvenirlik çalışması. Elektronik Sosyal Bilimler Dergisi, 15(59), 1250-1262

Diener, E., Emmons, R, Larsen, R., \& Griffin, S. (1985). The satisfaction with life scale. Journal of Personality Assessment, 49, 11051117.

Erol, S., Sezer, A., Şişman, F. N., \& Öztürk, S. (2016). Yaşlılarda yalnızlık algısı ve yaşam doyumu. Gümüșhane Üniversitesi Sağllk Bilimleri Dergisi, 5(3), 60-69.

Görgün Baran, A., Koçak Kurt, Ş., \& Serdar Tekeli, E. (2017). Yaşlıların dijital teknolojileri 
kullanım düzeyleri üzerine bir araștırma. İletişim Kuram ve Araștırma Dergisi, 45, 1-24.

Hill, R., Betts, L. R., \& Gardner, S. E. (2015). Older adults' experiences and perceptions of digital technology: (Dis)empowerment, wellbeing, and inclusion. Computers in Human Behavior, 48, 415-423.

Kalınkara, V., \& Sarı, İ. (2018). Yaşlıların bilgi teknolojileri kullanımı ve yaşam doyumu potansiyel ve engeller, ergonomik yaklaşım. Journal of Engineering Sciences and Design, 6 (ÖS: Ergonomi 2017), 1-13. DOI: $10.21923 /$ jesd.367367

Kalınkara, V., \& Sarı İ. (2019). Yaşlılarda sosyal ağ kullanımı ve yalnızlı ilișkisinin belirlenmesi. Yaşlı Sorunları Araştırma Dergisi, 12(1), 8-19.

Kapıkıran, Ş. (2016). Yaşlılarda yalnızlık ile yaşam doyumu arasındaki ilişki: Sosyal desteğin aracılık rolünün sınanması. Yaşlı Sorunları Araştırma Dergisi, 9(1), 13-25.

Karavidas, M., Lim, N. K., \& Katsikas, S. L. (2005). The effects of computers on older adult users. Computers in Human Behavior, 21(5), 697711.

Korkmaz, Ö., Usta, E., \& Kurt, İ. (2014). Sanal ortam yalnızlık ölçeği (SOYÖ) geçerlik ve güvenirlik çalışması. Hacettepe Üniversitesi Eğitim Fakültesi Dergisi, 29(2), 144-159.

Lissitsa, S. \& Chachashvili-Bolotin, S. (2016). İnternet çağında yaşam doyumu - Son on yılda meydana gelen değișik-likler. Insan Davranışında Bilgisayarlar, 54, 197-206.

Moody, E. J. (2001). Internet use and its relationship to loneliness. CyberPsychology \& Behavior, 4(3), 393-401.

Nowland, R., Necka, E. A., \& Cacioppo, J. T. (2018). Loneliness and social internet use: Pathways to reconnection in a digital world? Perspectives on Psychological Science, 13(1), 70-87.

Stepanikova, I., Nie, N. H., \& He, X. (2010). Time on the internet at home, loneliness, and life satisfaction: Evidence from panel time-diary data. Computers in Human Behavior, 26(3), 329-338.

Sum, S., Mathews, R. M., Hughes, I., \& Campbell, A. (2008). Internet use and loneliness in older adults. CyberPsychology \& Behavior, 11(2), 208-211.

Şahin, D.S., Özer, Ö., \& Yanardağ, M.Z. (2019). Perceived social support, quality of life and satisfaction with life in elderly people. Educational Gerontology, 45 (1), 69-77, DOI: 10.1080/03601277.2019.1585065

Şahin, B., \& Yıldırım, A. (2019). Yaşlı bireylerde internet kullanımı ile yaşam doyumu, algilanan sosyal destek ve umutsuzluk düzeyleri arasındaki ilişkinin incelenmesi. Yaşlı Sorunları Araştırma Dergisi, 12(2), 97-106.

Özen, Ü., \& Korukçu-Sarıcı, M. B. (2010). Yalnızlık olgusu ve sanal sohbetin yalnızlığın paylaşımına etkisi: Üniversite öğrencileri üzerinde bir araștırma. Atatürk Üniversitesi Íktisadi ve Ídari Bilimler Dergisi, 24(1), 149159.
Şimşek, N., Küçük Öztürk, G., \& Kaçmaz, H. Y. (2018). Yaşlılık ve yalnızlık. Uluslararası Sosyal Araștırmalar Dergisi, 11(58), 496-499.

Tekedere, H., \& Arpacı, F. (2016). Orta Yaş ve Yaşlı Bireylerin İnternet ve Sosyal Medyaya Yönelik Görüşleri. Türkiye Sosyal Araștırmalar Dergisi, 20(2), 377-392.

Temel, M., \& Şişman, F. N. (2017). İletişim becerileri eğitiminin hemșirelik ögrrencilerinin sanal ve kişilerarası ilişkilerine etkisi. Sağlık Bilimleri ve Meslekleri Dergisi, 4(3), 171-179.

TUIK,http://www.tuik.gov.tr/PreHaberBultenleri. do;jsessionid=2xn7pFGQlyhtGTVfhTTZ8Wp HtQJ0Xmd1LzQsPCbqg56lT9NrPCgL!-10551 67819?id=30574, Erişim Tarihi: 20.05.2020,

Ümmet, D., \& Ekşi, F. (2016). Türkiye'deki genç yetişkinlerde internet bağımlılı̆̆: Yalnızlık ve sanal ortam yalnızlık bağlamında bir inceleme. Addicta: The Turkish Journal on Addictions, 3(1), 29-53.

Young, K. S. (1998). Internet addiction: The emergence of a new clinical disorder. CyberPsychology \& Behavior, 1(3), 237-244.

Young, K. S. (1999). Internet addiction: symptoms, evaluation and treatment. Innovations in Clinical Practice, 17, 19-31. 